\title{
Anaphora Resolution in Hindi: Issues and Challenges
}

\author{
Triveni Lal Pal \\ Department of Computer \\ Science and Engineering \\ National Institute of Technology \\ Hamirpur \\ Hamirpur (H.P.), India
}

\author{
Kamlesh Dutta \\ Department of Computer \\ Science and Engineering \\ National Institute of Technology \\ Hamirpur \\ Hamirpur (H.P.), India
}

\author{
Pardeep Singh \\ Department of Computer \\ Science and Engineering \\ National Institute of Technology \\ Hamirpur \\ Hamirpur (H.P.), India
}

\begin{abstract}
Anaphora occurs very frequently in written texts and spoken dialogues. Almost all NLP applications such as machine translation, information extraction, automatic summarization, question answering system, natural language generation, etc., require successful identification and resolution of anaphora. Though the significant amount of work has been done in English and other European languages, the computational work, in reference to Hindi, is lagging far behind. In this paper, we present a review of work done in the field of anaphora resolution in Hindi. We also cover different issues and challenges in developing computational models for Hindi.. The paper covers issues related to syntactic/semantic structure of Hindi and influence of cases on pronouns, mainly personal pronoun. The work is mainly dedicated to pronominal anaphora. As the pronouns in Hindi do not differentiate gender, it is the verb and case markers that signify different genders. Influence of case markers in deciding the antecedent is explored. Pronoun resolution in context of EHMT (English-Hindi Machine Translation) systems is demonstrated to substantiate the need of anaphora resolution for NLP application.
\end{abstract}

\section{General Terms}

Natural Language Processing

\section{Keywords}

Anaphora, Anaphora Resolution, Case markers, Natural Language Processing, Pronominal Anaphora

\section{INTRODUCTION}

Anaphora is a referencing expression that refers to some entity which previously introduced into the discourse. The process of binding (mapping) the referring expression to the correct antecedent, in the given discourse, is called anaphora resolution. According to Halliday and Hassan [18], anaphora is "the cohesion (presupposition) which points back to some previous item." Hirst [5], more formally, defines anaphora as "a device for making an abbreviated reference (containing fewer bits of disambiguating information, rather than being lexically or phonetically shorter) to some entity (or entities) in the expectation that the receiver of the discourse will be able to disabbreviate the reference and, thereby, determine the identity of the entity." Here, reference is an anaphora and the entity to whom it refers, is an antecedent.

Among the various types (pronominal anaphora, nouns anaphora, nouns phrase anaphora and zero anaphora, as in [5]) of anaphora, pronominal is most common type of anaphora. Anaphora resolution is a challenging task in natural language processing because it need not only knowledge but expertise of almost all language processing domains (morphological and lexical knowledge, syntactic knowledge, semantic knowledge, discourse knowledge, real-world knowledge, etc.). Sometimes pragmatic knowledge is very important in anaphora resolution. This can be understood by following example:

1. S1: The Mangos were given to the children because they were hungry.

S2: The Mangos were given to the children because they were ripe.

S3: The Mangos were given to the children because they were there.

Who does each they refer to in the example 1 ? Because of the different interpretation of "they" in each sentence, the wholesome meaning of the sentence changes.

This paper is divided into two main parts. A literature survey of existing anaphora resolution approaches is presented in first part of the paper. Corresponding result on the basis of comparative study is presented. The second part of the paper concentrates on issues and challenges in anaphora resolution in Hindi.

\section{RELATED WORK IN ANAPHORA RESOLUTION}

Most of the earlier work done in the field of anaphora resolution is for English and other European languages. Hirst [5], have done extensive work to propose a computational solution to anaphora and co-reference resolution in English, as in [5]. Hobbs algorithm, as in [4], [22]; is an effective algorithm for anaphora resolution. It uses syntactic information rather than semantic information. The Hobbs algorithm, [9], depends only on a syntactic parser plus a morphological gender and number checker. For this reason, it is often used as a baseline, when evaluating new pronominal anaphora resolution algorithms. Mitkov's[21] work is very comprehensive in the field of anaphora resolution. JavaRAP [26] and Mitkov's Anaphora Resolution System [21] are among some good anaphora resolution systems.

Earlier, knowledge-based anaphora resolution approach relied on manually developed knowledge by linguists. This type of anaphora resolution is solved by hearer's set of beliefs (knowledge) that is used to represent syntax, semantic and 
discourse algorithm. These resolution approaches require inputs which are pre-processed manually and normally assumed to be perfect and if required has been check or modified by the experts. The difficulty to adapt the knowledge base system for other language and existence of preprocessing tools motivate the researchers to their focus into knowledge poor approaches (heuristic based systems).
Knowledge Poor (KP) systems provide simplicity and robustness design and are comparable in performance with knowledge based systems. Some examples of KP approach are Mitkov's Original Approach (MOA) [22], RAP [26] and ARN [6]. Brief comparison of these systems is given in Table 1 (as in [19]-[20]).

Table 1.Comparison of existing systems

\begin{tabular}{|c|c|c|c|c|c|}
\hline $\begin{array}{l}\text { Models/ } \\
\text { Element }\end{array}$ & MARS & RAP & MOA & Jepthah & $\mathbf{A R N}$ \\
\hline Data Sets & $\begin{array}{c}\text { Technical } \\
\text { Manual }\end{array}$ & $\begin{array}{c}\text { Computer } \\
\text { Manual }\end{array}$ & $\begin{array}{c}\text { Technical } \\
\text { Manual }\end{array}$ & $\begin{array}{c}\text { Manual Dialogues, G. } \\
\text { B. Shaw Play }\end{array}$ & $\begin{array}{c}\text { Oslo andBREDT } \\
\text { corpus }\end{array}$ \\
\hline Prerequisite & $\begin{array}{c}\text { Pre-processing } \\
\text { task } \\
\text { conducted } \\
\text { automatic } \\
\text { ally using } \\
\text { FDG } \\
\text { parser }\end{array}$ & $\begin{array}{l}\text { The data } \\
\text { manually check } \\
\text { and corrected } \\
\text { Pleonastic it } \\
\text { manually } \\
\text { remove }\end{array}$ & $\begin{array}{l}\text { The data } \\
\text { manually check } \\
\text { and corrected } \\
\text { Pleonastic it } \\
\text { manually } \\
\text { remove }\end{array}$ & $\begin{array}{l}\text { manually tagged } \\
\text { corpora, then be tuned } \\
\text { using Genetic } \\
\text { Algorithms }\end{array}$ & $\begin{array}{l}\text { manually tagged } \\
\text { corpora, then be tuned } \\
\text { using Genetic } \\
\text { Algorithms }\end{array}$ \\
\hline Purpose & $\begin{array}{l}\text { Third personal } \\
\text { pronouns and } \\
\text { lexical anaphora } \\
\text { (reflexives and } \\
\text { reciprocals) }\end{array}$ & $\begin{array}{l}\text { Third personal } \\
\text { pronouns and } \\
\text { lexicalanaphora } \\
\text { (reflexives and } \\
\text { reciprocals) }\end{array}$ & $\begin{array}{l}\text { Third personal } \\
\text { pronouns and } \\
\text { lexical anaphora } \\
\text { (reflexives and } \\
\text { reciprocals) }\end{array}$ & $\begin{array}{l}\text { pronouns, reflexives } \\
\text { and deictic anaphora }\end{array}$ & $\begin{array}{l}\text { Third personal } \\
\text { Pronoun exclude "it" }\end{array}$ \\
\hline Language & English & English & English & English & Norwegian \\
\hline $\begin{array}{c}\text { Reported } \\
\text { success rate }\end{array}$ & 61.55 & 84.10 & 89.70 & 72.50 & 70.50 \\
\hline
\end{tabular}

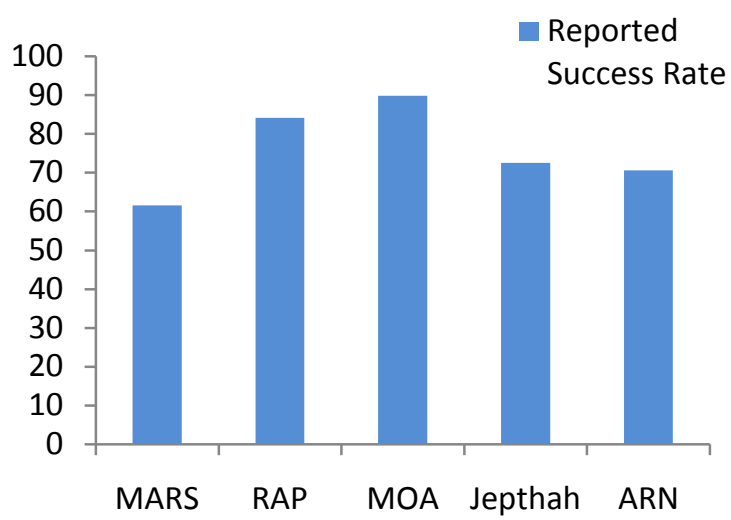

Fig 1: Comparison of success rate of different Anaphora Resolution Systems

\section{ANAPHORA RESOLUTION IN HINDI}

In Hindi and other Indian languages anaphora resolution studied are presented by Bharti et al. [1]. Authors designed methods to handle anaphora and ellipsis and implemented in a prototype natural language interface (NLI) to databases for Hindi. Parse structure of sentence has been formed by Panini parser developed at IIT Kanpur. Sobha and Patnaik[17] gave a rule based approach for the resolution of anaphora in Hindi and Malayalam as well. Anaphora resolution using rule based approach, corpus based studies, and using centering theory are presented in [24]-[25]. Prasad's thesis work is based on the principle that the grammatical function is important for discourse salience in Hindi Language, as in [24].

Dutta et al. [11] presented modified Hobbs algorithm for Hindi. The algorithm takes into account the free word-order and grammatical role in pronoun resolution in Hindi. Authors concluded that in Hindi, the role of subject and object are significant for reflexive and possessive pronouns. Dutta et al. [12] also highlighted the importance of anaphora resolution for machine translation application by evaluating the existing Machine translation systems: AnglaHindi by IIT Kanpur, Matra2 by CDAC Mumbai and Google translation system. Authors also highlighted the importance of application of pronominal divergence in machine translation and concluded that "pronominal divergence can help in identifying anaphoric and non-anaphoric occurrences of pronoun". Authors further highlight that machine translation is affected by improper anaphora resolution. They point out the issues in different translation systems. Where, Google translation, is unable to resolve the ambiguity between nominative and ergative forms of subject pronouns; MaTra2, on other hand, fails to specify correct forms of pronouns occurring in the object position. AnglaHindi has problem in making a choice of correct reflexive pronouns. The work of [13], [14] studied the application of machine learning algorithms and probabilistic neural network models on the demonstrative pronouns in Hindi. The work conducted so far, in [13], [14]; demonstrate that classification of demonstrative pronouns as direct and indirect anaphora is essential for successful anaphora resolution. The work is conducted on the Emille Corpus (http://www.emille.lancs.ac.uk/).The studies conducted so far, as in [12], demonstrate that, for a successful NLP application the resolution of anaphora is essential.

Recently, NLP tool contest on Anaphora Resolution in Indian Languages was organized in an annually conducted International Conference,ICON 2011 (9th International Conference on Natural Language Processing ) held at Anna University,

Chennai(http://ltrc.iiit.ac.in/icon2011/contests.html). The task included identification of antecedents for an anaphor from POS (Part Of Speech), NP (Noun Phrase) Chunked and NE (Named Entity) tagged corpus. Participants were provided 
with the training, development and test data. Efficiency of the system was measured using Precision and Recall.

\subsection{Anaphora Resolution and its \\ Importance in Machine Translation}

Anaphora resolution is crucial in many NLP applications such as machine translation, information extraction, automatic summarization, question answering system, natural language generation. Natural languages across the world are quite diverse in their structure. One language does not follow the syntax and semantics of other. For instance, it might happen that one language differentiate in gender of pronouns (like English, he, she, etc.), whereas other does not (like Hindi, veh, ve, etc.). Therefore, in order to translate/ generate correct sentence from source language to some target language, resolution of anaphoric expressions is crucially important. Solving the anaphora and extracting the antecedent are key issues for correct translation into the target language. If anaphors are not resolved properly, it may change the meaning of entire discourse. Example 2 illustrates what happen if anaphora not handled properly (http://www.bhaskar.com/article/NAT-anna-defends-hiscomment-on-pawar-slap-saying-he-is-not-gandhi2619674.html?RHS-badi_khabare=).

2. अन्नानेब्लॉगमेंआगेकहा, मेरीतुलनामहात्मागांधीसेकरनाठीकनहींहै, गाँधीजीकेपासबैठनेकीभीमेरीपात्रतानहींहै।

Google translation of same in English-

Annasaidinthe blog, is not fair tocompare mewithMahatmaGandhi, Gandhiis noteligibleto sit close tome.

The real sense of the sentence is "I am not even eligible to sit close to Gandhi ji". But the sentence is changed in translation just to reverse the meaning. This type of translation cannot be accepted. This happens because references are not properly resolved in English translation. Some other examples are shown in Table 2-4 (sentences as translated by different English-Hindi MT systems, for different pronouns).

\subsubsection{Possessive Pronouns}

Table 2. Examples of possessive pronouns

\begin{tabular}{|l|l|l|}
\hline $\begin{array}{l}\text { ENGLIS } \\
\text { (SOURC } \\
\text { E } \\
\text { SENTEN } \\
\text { CE) }\end{array}$ & $\begin{array}{l}\text { GOOGLE } \\
\text { TRANSLATION }\end{array}$ & $\begin{array}{l}\text { MATRA2 } \\
\text { TRANSLATION }\end{array}$ \\
\hline $\begin{array}{l}\text { I saw her } \\
\text { book on } \\
\text { your } \\
\text { table. }\end{array}$ & $\begin{array}{l}\text { मैंअपनीमेजपरउसेपु } \\
\text { स्तकदेखा. }\end{array}$ & $\begin{array}{c}\text { मैनेतुम्हारामेजपरउसकाकि } \\
\text { ताबदेखी । }\end{array}$ \\
\hline $\begin{array}{l}\text { The } \\
\text { house is } \\
\text { theirs and } \\
\text { its paint is } \\
\text { flaking. }\end{array}$ & $\begin{array}{l}\text { घरअरउनकीअपनीपें } \\
\text { ट flaking है. }\end{array}$ & $\begin{array}{c}\text { घरठेिरसहैऔरउसकारंगप } \\
\text { रतकररहाहै । }\end{array}$ \\
\hline $\begin{array}{l}\text { My dog is } \\
\text { better } \\
\text { than their } \\
\text { dog. }\end{array}$ & $\begin{array}{l}\text { मेराकुत्ताअपनेकुत्ते } \\
\text { सेबेहतरहै. }\end{array}$ & $\begin{array}{l}\text { मेराकुत्ताउनकाकुत्तासेअ } \\
\text { च्छाहै । }\end{array}$ \\
\hline
\end{tabular}

In the fourth sentence (Table 2), mine should be resolved as "mera" (of my), but MATRA2 (http://www.cdacmumbai.in/matra/) unable to resolve it.

\subsubsection{Reflexive Pronouns}

Reflexive pronouns ends as "...self" or "...selves" and rename subjects of action verbs. They function as various types of objects. For example 'myself', 'yourself', 'himself', 'herself', 'itself' are singular and 'ourselves', 'yourselves', 'themselves' are plural reflexive pronouns. As in the Table 3, reflexive pronouns are not properly handled by both the translation systems.

Table 3. Examples of reflexive pronouns

\begin{tabular}{|c|c|c|}
\hline $\begin{array}{l}\text { ENG } \\
\text { LIS } \\
\text { H } \\
\text { (SO } \\
\text { URC } \\
\text { E } \\
\text { SEN } \\
\text { TEN } \\
\text { CE) }\end{array}$ & $\begin{array}{l}\text { GOOGLE } \\
\text { TRANSLATION }\end{array}$ & $\begin{array}{l}\text { MATRA2 } \\
\text { TRANSLATION }\end{array}$ \\
\hline $\begin{array}{l}\text { She } \\
\text { boug } \\
\text { ht } \\
\text { herse } \\
\text { lf a } \\
\text { new } \\
\text { purse } \\
\text { for } \\
\text { her } \\
\text { new } \\
\text { job. }\end{array}$ & $\begin{array}{l}\text { वहखुदउसेनईनौकरीकेलि } \\
\text { एएकनयाबटुआखरीदाहै. }\end{array}$ & $\begin{array}{l}\text { उन्होनेखुदउसकानयाकामके } \\
\text { लियेएकनयाबटुआखरीदा । }\end{array}$ \\
\hline $\begin{array}{l}\text { They } \\
\text { mana } \\
\text { ged } \\
\text { them } \\
\text { selve } \\
\text { s } \\
\text { very } \\
\text { well } \\
\text { as } \\
\text { mem } \\
\text { bers } \\
\text { of the } \\
\text { confe } \\
\text { rence } \\
\text { panel }\end{array}$ & $\begin{array}{l}\text { वेखुदसम्मेलनपैनलकेसद } \\
\text { स्योंकेरूपमेंबहुतअच्छीत } \\
\text { रहसेप्रबंधित. }\end{array}$ & $\begin{array}{l}\text { वेखुदकीसदस्यकेरूपमेंसम्मे } \\
\text { लनपैनलकाबहुतअच्छीतरह } \\
\text { कीदेखबालकिये। }\end{array}$ \\
\hline $\begin{array}{l}\text { He } \\
\text { loved } \\
\text { hims } \\
\text { elf } \\
\text { too } \\
\text { much } \\
\text {, and } \\
\text { never } \\
\text { thoug } \\
\text { ht } \\
\text { about } \\
\text { anyo } \\
\text { ne } \\
\text { else. }\end{array}$ & $\begin{array}{l}\text { उसनेअपनेआपकोबहुत } \\
\text { ज्यादाप्यारकरताथा, } \\
\text { औरकिसीऔरकेबारेमेंक } \\
\text { भीनहींसोचा. }\end{array}$ & $\begin{array}{l}\text { उन्होनेकोईअन्यकेबारेमेंपस } \\
\text { न्दकियाखुदबःउतबहुत । }\end{array}$ \\
\hline
\end{tabular}




\subsubsection{Demonstrative Pronoun}

Table 4. Examples of demonstrative pronouns

\begin{tabular}{|l|l|l|}
\hline $\begin{array}{l}\text { ENGLISH } \\
\text { (SOURCE } \\
\text { SENTENC } \\
\text { E) }\end{array}$ & $\begin{array}{l}\text { GOOGLE } \\
\text { TRANSLATION }\end{array}$ & $\begin{array}{l}\text { MATRA2 } \\
\text { TRANSLATION }\end{array}$ \\
\hline $\begin{array}{l}\text { I like this } \\
\text { better than } \\
\text { that. }\end{array}$ & $\begin{array}{l}\text { मैंइसतरहसेहैकिबेह } \\
\text { तर. }\end{array}$ & $\begin{array}{l}\text { मैंयहउनसेअच्छापसन्दकर } \\
\text { तीहूँ। }\end{array}$ \\
\hline $\begin{array}{l}\text { This is } \\
\text { great. }\end{array}$ & यहमहानहै. & यहबड़ाहै। \\
\hline $\begin{array}{l}\text { These look } \\
\text { tasty. }\end{array}$ & येस्वादिष्टदेखो. & येस्वादिष्टदेखताहै। \\
\hline
\end{tabular}

Table 5.Several translation systems with good reported results

\begin{tabular}{|c|c|c|c|}
\hline Element & SUPAR & AGIR & SYSTRANLinks \\
\hline Data Sets & CRATER corpus & SemCor corpus, MTI corpus & Unrestricted text \\
\hline Prerequisite & $\begin{array}{l}\text { Texts from CRATER corpus } \\
\text { automatically tagged by the } \\
\text { Spanish version of the Xerox } \\
\text { tagger. }\end{array}$ & $\begin{array}{l}\text { Partial parsing technique has } \\
\text { been applied then interlingua } \\
\text { representation of entire text has } \\
\text { been obtained }\end{array}$ & \\
\hline Purpose & $\begin{array}{l}\text { Resolves several kinds of } \\
\text { anaphora pronominal } \\
\text { references, surface-count } \\
\text { anaphora, one-anaphora, } \\
\text { definite noun phrases and VP- } \\
\text { anaphora }\end{array}$ & $\begin{array}{l}\text { Translation of inter sentential } \\
\text { anaphora, detection of co- } \\
\text { reference chains, translation of } \\
\text { Spanish zero pronouns into } \\
\text { English. }\end{array}$ & $\begin{array}{c}\text { Commercial product for } \\
\text { translation between English and } \\
\text { Spanish }\end{array}$ \\
\hline Language & Spanish & Spanish, English & Spanish \\
\hline Reported success rate & 76.25 & 80.4 Spanish, 84.8 English & 56.9 \\
\hline
\end{tabular}

We have studied some key systems which deal with several kind of anaphora with good results and presented them in Table 5[2], [8]. Though, these systems are not for Hindi, but can be quite helpful in developing the concept for anaphora resolution in Hindi.

\section{ISSUES IN ANAPHORA RESOLUTION IN HINDI}

Large amount of information is available in Hindi on www (on electronic document form). But this information is encoded in different fonts. That is, there is difficulty in encoding the document in some standard form. Unicode might be a solution to this problem of standardization. But there is another problem that all the sites does not use Unicode based tools. The second problem with Unicode based font is that Unicode based tools may not support Hindi. This lack of standardization limits the use of these documents in developing corpus. Therefore, neither a single corpus nor a language processing tool is developed and freely available for research. The tools available are either not up to the mark or limited to some specific domain only.

Anaphora resolution can improve the performance of many NLP applications like question answering system, short

\begin{tabular}{|l|l|l|}
\hline $\begin{array}{l}\text { I really like } \\
\text { that. }\end{array}$ & मैंसचहैकिपसंदहै. & $\begin{array}{l}\text { मैंयथार्थमेवहपसन्दकरता } \\
\text { है । }\end{array}$ \\
\hline
\end{tabular}

In the first sentence (Table 4) 'this' and 'that' are demonstrative pronouns used to represent closeness of object from speaker but Google translator (http://translate.google.co.in/?hl=en\&tab=TT ) does not able to resolve 'that' pronouns. It takes 'that' as subordinating conjunction not as demonstrative pronoun. On the other hand MaTra2 is able to resolve somehow better than Google in this sentence. Similarly in the last sentence, "I really like that", "that" is resolved as subordinating conjunction rather than demonstrative. Whereas MaTra2 resolve as expected. answer examination system, information extraction system, etc. consider the example 3-5.

3. आमबच्चोंकोदेदिएगएक्योंकिवेभूंखेथे.

The Mangos were given to the children because they were hungry.

4. आमबच्चोंकोदेदिएगएक्योंकिवेपकेथे.

The Mangos were given to the children because they were ripe.

5. आमबच्चोंकोदेदिएगएक्योंकिवेवहांथे.

The Mangos were given to the children because they were there.

Consider the application of question answering, if the question asked कौन भूखे थे (who were hungry)? The answer will only be given if pronoundे (they) is correctly resolved with the antecedent. The possible antecedents for "they" are "the mangos" and "children". In all the sentences in example $3-5$, each "they" refers to different antecedent. Whereas in the example 3 they refers to the "children", in example 4, refers to the "mangos" and again in the last sentence they refers to the "children". 


\subsection{Cases and their Influence in Pronoun Resolution}

As the Hindi does not differentiate pronouns on gender, its verb that differentiate masculine from feminine gender. Therefore knowledge of verb is also essential correct pronoun resolution. Despite knowledge about verb, there is one more important element which influences anaphora resolution in Machine Translation. In Hindi, cases plays very important role in correct translation of some source text in some foreign language to target text in Hindi. Therefore study of cases and their influence on pronoun resolution is also important.
In Hindi the pronouns are inflected depending on the number and case. In Hindi, pronouns may be classified into six categories, namely personal (purush vachak) pronoun, demonstrative (nischay vachak) pronoun, indefinite (anischay vachak) pronoun, relative (sambandh vachak) pronoun, interrogative (prashna vachak) pronoun and reflexive (nij vachak) pronoun. Among these the most important is the personal pronoun category. We present only about them here. The Table 6shows various personal pronouns according to first, second and third person.

Table 6. Personal pronouns with different cases

\begin{tabular}{|c|c|c|c|c|c|c|c|}
\hline \multicolumn{3}{|c|}{ Cases/Person } & 1st & 2nd (intimate) & $\begin{array}{c}\text { 2nd } \\
\text { (honorific) }\end{array}$ & 3rd (proximal) & 3rd (distal) \\
\hline \multirow{2}{*}{ Direct } & \multicolumn{2}{|c|}{ Singular } & मैंMain (I) & तूTu(You) & आप $A a p(\mathrm{You})$ & $\begin{array}{c}\text { यहYeh(This/It/He/ } \\
\text { She) }\end{array}$ & वहVeh(That/He/She \\
\hline & \multicolumn{2}{|c|}{ Plural } & हमHum(We) & तुमTum(You) & आपAap (You) & ये $Y e$ (These/They) & वेVe(Those/They) \\
\hline \multirow{2}{*}{ Dative } & \multicolumn{2}{|c|}{ Singular } & $\begin{array}{c}\text { मुझे/मुझकोMujhel } \\
\text { Mujhko }\end{array}$ & $\begin{array}{c}\text { तुम्हे/तुमकोTumhen } \\
\text { /Tumko }\end{array}$ & आपकोAapko & इसे/इसकोIse/Isko & उसे/उनकोUse/Unko \\
\hline & \multicolumn{2}{|c|}{ Plural } & $\begin{array}{c}\text { हमें/हमकोHumen/ } \\
\text { Humko }\end{array}$ & $\begin{array}{c}\text { तुम्हें/तुमकोTumhen } \\
\text { /Tumko }\end{array}$ & आपकोAapko & $\begin{array}{c}\text { इन्हें/इनकोInhen/In } \\
\text { ko }\end{array}$ & $\begin{array}{c}\text { उन्हें } \\
\text { उनकोUnhen/Unko }\end{array}$ \\
\hline \multirow{4}{*}{$\begin{array}{c}\text { Genitiv } \\
\text { e / } \\
\text { possess } \\
\text { ive }\end{array}$} & \multirow{2}{*}{$\begin{array}{l}\text { Sin } \\
\text { gul } \\
\text { ar }\end{array}$} & $\begin{array}{l}\text { masc } \\
\text { uline }\end{array}$ & $\begin{array}{l}\text { मेराMera }(\mathrm{my} / \mathrm{min} \\
\text { e) }\end{array}$ & $\begin{array}{c}\text { तेराTera(thine/your } \\
\text { s) }\end{array}$ & $\begin{array}{c}\text { आपकाAapka(y } \\
\text { our/yours) }\end{array}$ & $\begin{array}{l}\text { इसकाIska(of } \\
\text { this/Its/his) }\end{array}$ & उसका $U s k a$ (his) \\
\hline & & $\begin{array}{l}\text { femi } \\
\text { nine }\end{array}$ & $\begin{array}{c}\text { मेरीMeri (my/mine } \\
\text { ) }\end{array}$ & $\begin{array}{c}\text { तेरीTeri } \\
\text { (thine/yours) }\end{array}$ & $\begin{array}{c}\text { आपकीAapki(y } \\
\text { our/yours) }\end{array}$ & $\begin{array}{l}\text { इसकी Iski(of } \\
\text { this/Its/her) }\end{array}$ & उसकी Uski(her) \\
\hline & \multirow{2}{*}{$\begin{array}{l}\text { Plu } \\
\text { ral }\end{array}$} & $\begin{array}{l}\text { masc } \\
\text { uline }\end{array}$ & $\begin{array}{c}\text { हमारीHumaree(o } \\
\text { ur/ours) }\end{array}$ & $\begin{array}{c}\text { तुम्हाराTumhara(yo } \\
\text { ur/yours) }\end{array}$ & $\begin{array}{c}\text { आपकाAapka(y } \\
\text { our/yours) }\end{array}$ & इनकाInka(their) & उनकाUnka (their) \\
\hline & & $\begin{array}{l}\text { femi } \\
\text { nine }\end{array}$ & & तुम्हारी(your/yours) & $\begin{array}{c}\text { आपकी(your/yo } \\
\text { urs) }\end{array}$ & इनकी (theirs) & उनकी (their) \\
\hline \multirow{2}{*}{$\begin{array}{c}\text { Ablativ } \\
\text { e }\end{array}$} & \multicolumn{2}{|c|}{ Singular } & मुझसेMujhse & $\begin{array}{c}\text { तुझसे/तुमसेTujhse/ } \\
\text { Tumse }\end{array}$ & आपसेAapse & इससेIsse & उससेUsse \\
\hline & \multicolumn{2}{|c|}{ Plural } & हमसेHumse & तुमसेTumse & आपसेAapse & इनसेInse & उनसेUnse \\
\hline \multirow{2}{*}{$\begin{array}{c}\text { Locativ } \\
\text { e }\end{array}$} & \multicolumn{2}{|c|}{ Singular } & मुझपरMujhpar & तुझपरTumpar & आपपरAappar & इसपरIspar & उसपरUspar \\
\hline & \multicolumn{2}{|c|}{ Plural } & हमपरHumpar & तुमपरTumpar & आपपरAappar & इनपरInpar & उनपरUnpar \\
\hline \multirow{2}{*}{$\begin{array}{l}\text { Ergativ } \\
\text { e }\end{array}$} & \multicolumn{2}{|c|}{ Singular } & मैंनेMaine & तुनेTune & आपनेAapne & इसनेlsne & उसनेUsne \\
\hline & \multicolumn{2}{|c|}{ Plural } & हमनेHumne & तुमनेTumne & आपनेAapne & इन्होंनेInhonne & उन्होंनेUnhonne \\
\hline
\end{tabular}

The Table 6 shows how personal pronoun changes as the cases changes from direct to dative, genitive and other forms. There are always separate forms of intimate and honorific second person pronoun in the same case. But the honorific second person pronoun remains the same for both singular and plural. Generally, dative case shows the noun/pronoun to whom, something is given. For example, in "Ram gave
Shyam a book". The thing given to Shyam is "book" which is tangible object it may also be intangible like "advice". The dative, generally, marks the indirect object of a verb. Generally, ablative pronoun/nouns represent a motion away from something. Ablative pronouns in Hindi sentences can be roughly corresponds to some work done by 
somebody/something. The next section covers another issue in anaphora resolution i.e., pleonastic "it".

\subsection{Pleonastic 'it'}

Though pleonastic 'it' has great importance in English language, more often it is quite irrelevant to translate in Hindi. But its appearance has pronoun create big difficulty. This can be clearer from Example 6, a sentence in English language-

6. It is bright sun shine today.

It has corresponding translation in Hindi as "aaj tej dhoop hai". Though the corresponding translation of "it" in Hindi be "yeh" or "veh", in the given example it have no mapping. Therefore it quite irrelevant to translate this type of "it" in Hindi target text form English source text. Frequent occurrences of this type of "it" can cause problem in machine translation. Therefore, for a good translation, it is quite necessary to point out the situations where "it" is treated as pronoun (the translation of "it" as "yeh" or "veh"), and the situations where "it" have to be dropped (pleonastic "it") [12].

\section{CONCLUSION}

Anaphora resolution is very important in almost all NLP applications. As in Hindi, there is not a significant amount of work has been done this paper presents the issues and challenges in anaphora resolution in Hindi. Comparison table shows the reported success rate of different methods for anaphora resolution (especially in machine translation). Forms of pronouns has been changed according to cases, discussed and presented in Table 6. Pleonastic "it" also influences the resolution processes. We, in this paper, only discuss the different issues in the anaphora resolution (especially pronominal anaphora) in Hindi. In future we will try to develop a model for anaphora resolution in Hindi.

\section{REFERENCES}

[1] A Bharati, Y Krishna Bhargava and R. Sangal, "reference and ellipsis in an indian languages interface to database," computer science and informatics, IIT Hyderabad, 1993, VOL 23; NUMBER 3, pages 60.

[2] A. Ferrandez, M. Palomar and L. Moreno, "Slot unification grammar \& anaphora resolution," BIOTECHNOLOGY NEWSWATCH, 2000, 4-SEP2000, pages 11-12.

[3] C. Kennedy and B. Boguraev, "Anaphora for everyone: pronominal anaphora resolution without a parser," Proceedings of the 16th International Conference on Computational Linguistics (COLING'96), 113-118. Copenhagen, Denmark, 1996.

[4] D. Jurafsky and J. Martin, "Speech and language processing. An introduction to natural language processing, computational linguistics, and speech recognition," Upper Saddle River, NJ: Prentice Hall, 2010 .

[5] G. Hirst, "Anaphora in Natural Language Understanding," Springer-Verlag, Berlin, 1981.

[6] G. I. Holen, "Automatic Anaphora Resolution for Norwegian (ARN)," in Deptartement of Linguistics and Scandinavian Studies. vol. Master Norway: UNIVERSITY OF OSLO, 2006, p. 142.

[7] H. Ho, K. Min and W. Kiang Yeap, "Pronominal Anaphora Resolution Using a Shallow Meaning Representation of Sentences," 8th Pacific Rim
International Conference on Artificial Intelligence, Auckland, New Zealand, 2004.

[8] J. Peral and A. Ferrandez, "Translation of Pronominal Anaphora between English anad Spanish: Discrepancies and Evaluation," Journal of Artificial Intelligence Research 18, 2003, 117-147.

[9] J. R. Hobbs,J. R., “ Pronoun Resolution," Research Report 76-1, Department of Computer Science, City College, New York., August 1976.

[10] K. Dutta, S. Kaushik and N. Prakash, "Hybrid framework for Information Extraction for geographical terms in Hindi Language Texts," Proceedings of IEEE International, Natural Language Processing and Knowledge Engineering, IEEE NLP-KE '05, 2005.

[11] K. Dutta, N. Prakash and S. Kaushik, "Resolving Pronominal Anaphora in Hindi using Hobbs' algorithm," Web Journal of Formal Computation and Cognitive Linguistics, Issue 10, 2008.

[12] K. Dutta, N. Prakash and S. Kaushik, "Application of Pronominal Divergence and Anaphora Resolution in English-Hindi Machine Translation," Research journal "POLIBITS" Computer Science and Computer Engineering with Applications, Issue 39, pp-55-58, 2009.

[13] K. Dutta, N. Prakash and S. Kaushik, "Probabilistic Neural Network Approach to the Classification of Demonstrative Pronouns for Indirect Anaphora in Hindi," Expert Systems with Applications: An International Journal, Volume 37, Issue 8, pp. 56075613, Elsevier, 2010.

[14] K. Dutta, S. Kaushik and N. Prakash, "Machine Learning Approach for the Classification of Demonstrative Pronouns for Indirect Anaphora in Hindi News Items," Prague Bulletin of Mathematical Linguistics. Versita, Vol. 95, pp. 33-50, 2011

[15] K. E. Lejtovicz and Z. T. Kardkovács, "Anaphora Resolution," in 8th International Symposium of Hungarian Researchers on Computational Intelligence and Informatics Hungary, 2007, pp. 591- 599.

[16] L. Sobha and B.N. Patnaik, "Vasisth: An Anaphora Resolution System for Indian Languages," International Conference on Artificial and Computational Intelligence for Decision, Control and Automation in Engineering and Industrial Applications, Monastir, Tunisia, 2000.

[17] L. Sobha and B.N. Patnaik, "Vasisth: An anaphora resolution system for Malayalam and Hindi", Symposium on Translation Support Systems, 2002.

[18] M. Halliday and R. Hasan, "Cohesion in English," Longman English Language Series 9, Longman, 1976.

[19] N. K. M. Noor, M. J. A. Aziz, S. A. Noah and M. P. Hamzah, "Anaphora resolution of Malay Text: Issues and Proposed Solution Model," International conference on Asian Language Processing, 2010.

[20] P. Jain, M. Mittal, A. Mukerjee and A. Raina, "Anaphora Resolution in Multi-Person Dialogue, Strube, M. and Candy Sidner (ed.)," Proceedings of the 5th SIGdial Workshop on Discourse and Dialogue, Association for Computational Linguistics, Boston, Cambridge, Massachusetts, 2004. 
[21] R. Mitkov, R. Evans and C. Orasan, "A new, fully automatic version of Mitkov's knowledge-poor pronoun resolution method," LECTURE NOTES IN COMPUTER SCIENCE, 2002, ISSU 2276, pp.168-186.

[22] R. Mitkov, "An integrated model for anaphora resolution," in Proceedings of the 15th conference on Computational linguistics - Volume 2 Kyoto, Japan: Association for Computational Linguistics, 1994.

[23] R. Mitkov and Wolverhampton WV SB, "Anaphora Resolution: The State of The Art," Technical Report. School of Languages and European Studies, University of Wolverhampton, Stanford Street, Wolverhampton WV1 1SB, United Kingdom, 1999.
[24] R. Prasad, "Constraints on the generation of referring expressions: with special reference to Hindi," (Ph.D. thesis), University of Pennsylvania, 2003.

[25] R. Prasad and M., "Discourse salience and pronoun resolution in Hindi," In Williams, A. \& Kaiser, E. (eds.) Penn Working Papers in Linguistics: Current Work in Linguistics 6(3), 189-208, 2000.

[26] S. Lappin and H. Leass, "An algorithm for pronominal anaphora resolution," Computational Linguistics, 20(4), 535-561,

1994. 